\title{
Microdetermination of Adrenocortical Steroids by Double Isotope Method (II) Fractional Determination of Corticosteroids: Free and Protein-Bound Cortisol, Corticosterone in Plasma
}

\author{
AKIRA KUNUGI, Ushiho MATSUMOTO AND YUzo NAGASE \\ Department of Analytical Chemistry, \\ Tokyo College of Pharmacy, Tokyo,
}

\begin{abstract}
Synopsis
Further examination were made on the double isotope derivative dilution method by the use of thiosemicarbazide- ${ }^{35} \mathrm{~S}$ as the labeled reagent and ${ }^{3} \mathrm{H}$-labeled corticosteroid for correcting the loss during extraction and separation procedure, and fractional determination of free and protein-bound cortisol and corticosterone. $\Delta^{4}-3$-Ketosteroids with similar chemical structure present in plasma, namely cortisol, corticosterone, aldosterone, deoxycorticosterone, and cortisone can be separated by repeating thinlayer chromatography at a low temperature of $10^{\circ} \mathrm{C}$, more than four times. Cortisol and corticosterone can be determined correctly and with good precision, relative standard deviation being $1-2 \%$. Other three corticosteroids can be determined correctly and with good precision, relative standard deviation being 3-6\%.

It was found that the protein-bound cortisol and corticosterone in plasma are dissociated during solvent extraction and the total amount is determined in free form. It was also found that the protein-bound and free cortisol and corticosterone can be separated by gel filtration, and the combination of gel filtration and the present method of determination has made it possible to carry out fractional determination of bound and free forms of cortisol and corticosterone. From its results, the quantity per $100 \mathrm{~m} l$ of plasma was found to be 1.83 and $0.18 \mu \mathrm{g}$ of free cortisol and corticosterone, and 17.45 and $1.75 \mu \mathrm{g}$ of protein-bound cortisol and corticosterone, respectively.
\end{abstract}

In the work reported in the preceding paper (Kunugi et al., 1972), fundamental conditions had been examined for the microdetermination of cortisol and corticosterone by the double isotope derivative dilution analysis, in which thiosemicarbazide $-{ }^{35} \mathrm{~S}$ was used as the labeled reagent. It is known that the amount of corticosteroids present in blood varies markedly with function of adrenal cortex, pituitary, and thyroid gland, and also that the administration of synthetic corticosteroid preparation results in variation of the secretion of corticosteroids from the adrenal cortex. Corticosteroids and synthetic steroids administered or progesterone and testosterone

Received for publication December 4, 1972. interfere to each other in the determination of cortisol, corticosterone, aldosterone, deoxycorticosterone, and cortisone in plasma because of the similarity of their chemical structure. It is also likely that some components present in blood that having a carbonyl group, like glucose and acetone, would affect the present determination, since these components also react with thiosemicarbazide- ${ }^{35} \mathrm{~S}$.

In the present work, therefore, effect of the coexisting glucose and acetone were examined, because of the $\mathrm{Rf}$ values of glucose and acetone thiosemicarbazones are fairly close to that of corticosteroid thiosemicarbazones. By means of repeating thin-layer chromatography (TLC), these coexisting components are mutually separated, it is possible to carry out 
simultaneous determination of cortisol, corticosterone, aldosterone, deoxycorticosterone, and cortisone in plasma.

It is known that majority of corticosteroids in blood, under a physiological condition, is specifically bound with transcortin, a corticosteroid-binding $\alpha$-globulin (Daughaday, 1958; Slaunwhite and Sandberg, 1959; Seal and Doe, 1962). Examinations were therefore made on the effect of the binding of corticosteroids with plasma protein on this determination, and fractional determination of free and protein-bound cortisol and corticosterone.

\section{Materials and Methods}

\section{Reagents}

Cortisol $\left[1,2-{ }^{3} \mathrm{H}\right]$ : Cortisol $\left[1,2-{ }^{3} \mathrm{H}\right]$ (specific activity, $20 \mathrm{Ci} / \mathrm{mmole}$ ) (Radiochemical Center, Amersham, England) was purified on use by TLC using a solvent system of chloroform-ethanol $(9: 1)$. Corticosterone $\left[1,2-{ }^{3} \mathrm{H}\right]$ : Corticosterone $\left[1,2-{ }^{3} \mathrm{H}\right]$ (specific activity, $10 \mathrm{Ci} / \mathrm{mmole}$ ) (Radiochemical Center) was purified in the same way as cortisol $\left[1,2-{ }^{3} \mathrm{H}\right]$. Aldosterone $\left[1,2-{ }^{3} \mathrm{H}\right]$ : Aldosterone $\left[1,2-{ }^{3} \mathrm{H}\right]$ (specific activity, $17 \mathrm{Ci} / \mathrm{mmole}$ ) (Radiochemical Center) was purified in the same way as cortisol $\left[1,2{ }^{3} \mathrm{H}\right]$. Deoxycorticosterone $\left[1,2-{ }^{3} \mathrm{H}\right]$ : Deoxycorticosterone [1,2${ }^{3} \mathrm{Hl}$ (specific activity, $30 \mathrm{Ci} / \mathrm{mmole}$ ) (New England Nuclear Corp., Boston, Mass.) was purified in the same way as cortisol $\left[1,2-{ }^{3} \mathrm{H}\right]$. Cortisone $\left[1,2-{ }^{3} \mathrm{H}\right]$ : Cortisone $\left[1,2-{ }^{3} \mathrm{H}\right]$ (specific activity, $53 \mathrm{Ci} / \mathrm{mmole}$ ) (New England Nuclear Corp.) was purified in the same way as cortisol $\left[1,2-{ }^{3} \mathrm{H}\right]$. Thiosemicarbazide- ${ }^{35} \mathrm{~S}$ : Synthesizes by the same method as described in the preceding paper (Kunugi et al., 1972). Silica Gel: Wakogel B-5F (Wako Pure Chemicals, Tokyo) was used. Sephadex: Sephadex G-25 Fine (Pharmacia Fine Chemicals, Uppsala, Sweden) was used. Phosphate buffer ( $\mathrm{pH}$ 7.38): Prepared from $200 \mathrm{ml}$ of $\mathrm{M} / 15 \mathrm{KH}_{2} \mathrm{PO}_{4}$ and $800 \mathrm{~m} l$ of $\mathrm{M} / 15 \mathrm{Na}_{2} \mathrm{HPO}_{4}$. Lipophilic liquid scintillator: Prepared by dissolving $4 \mathrm{~g}$ of PPO and $0.1 \mathrm{~g}$ of dimethyl-POPOP in 1 liter of toluene. Hydrophilic liquid scintillator: Prepared by dissolving $4 \mathrm{~g}$ of PPO, $0.4 \mathrm{~g}$ of dimethyl-POPOP, and $100 \mathrm{~g}$ of naphthalene in 1 liter of toluene-dioxane-methylcellosolve $(15: 3: 2, \mathrm{v} / \mathrm{v})$.

\section{Determination Procedures}

1. Determination of Corticosteroids in Plasma by Double Isotope Derivative Dilution Method

Extraction from plasma (Step 1): To $1 \mathrm{ml}$ of plasma, $1 \times 10^{5} \mathrm{dpm}$ each of ${ }^{3} \mathrm{H}$-labeled cortisol, corticosterone, aldosterone, deoxycorticosterone, and cortisone were added, the mixture was washed three times with $1 \mathrm{ml}$ each of petroleum ether, and extracted three times with $5 \mathrm{ml}$ each of dichloromethane. The extract was washed consecutively with cold $0.1 \mathrm{~N}$ $\mathrm{NaOH}$ solution, $0.1 \mathrm{~N} \mathrm{H}_{2} \mathrm{SO}_{4}$, and water to obtain a crude extract.

Formation of corticosteroid thiosemicarbazones${ }^{35} \mathrm{~S}$ (Step 2): A mixture of the crude extract, $100 \mu \mathrm{g}$ of thiosemicarbazide- ${ }^{35} \mathrm{~S}$ (III), and $1 \mathrm{ml}$ of $10 \%$ methanolic solution of acetic acid was added and the mixture was heated at $65^{\circ} \mathrm{C}$ for $90 \mathrm{~min}$. After addition of $2 \mathrm{ml}$ of $\mathrm{Na}_{2} \mathrm{CO}_{3}$ solution $(59.5 \mathrm{mg} / \mathrm{ml})$, the mixture was extracted with three $5 \mathrm{ml}$ portions of dichloroethane. The extract was washed consecutively with water, $1 \%$ thiosemicarbazide solution, and water to obtain corticosteroid thiosemicarbazones.

Separation of thiosemicarbazones (Step 3): To the extract solution, $20 \mu \mathrm{g}$ each of unlabeled corticosteroid thiosemicarbazones were added as a carrier and the mixture was submitted to four repeated TLC consecutively with the solvent systems of chloroform-ethanol (9:1), cyclohexane-isopropanol $(7: 3)$, benzene-acetone $(1: 1)$, and ethyl acetate to separate the desired corticosteroid thiosemicarbazones.

Radioactivity measurement (Step 4): The silica gel in the area of the spot absorbing ultraviolet (UV) ray was scraped off, eluted with methanol-dichloroethane $(1: 1)$, and eluate was collected in a counting vial. After evaporation of the solvent, $10 \mathrm{ml}$ of lipophilic liquid scintillator was added and radioactivities of ${ }^{3} \mathrm{H}$ and ${ }^{35} \mathrm{~S}$ were measured in a liquid scintillation counter.

The amount of corticosteroids in the sample was calculated from the following formula.

$$
\mathrm{C}_{p}=\mathrm{C}_{s} \times \frac{\mathrm{S}_{p}}{\mathrm{H}_{p}} \times \frac{\mathrm{H}_{s}}{\mathrm{~S}_{s}} \times \frac{\mathrm{I}_{p}}{\mathrm{I}_{s}}
$$

where $\mathrm{C}_{p}$ : amount (in $\mu \mathrm{g}$ ) of corticosteroid in sample. $\mathrm{C}_{s}$ : amount (in $\mu \mathrm{g}$ ) of corticosteroid added to the standard sample. $\mathrm{S}_{p}$ and $\mathrm{H}_{p}$ : dpm of ${ }^{35} \mathrm{~S}$ and ${ }^{3} \mathrm{H}$ in the sample after analytical procedures. $\mathrm{S}_{s}$ and $\mathrm{H}_{s}$ : dpm of ${ }^{35} \mathrm{~S}$ and ${ }^{3} \mathrm{H}$ in the standard sample after analytical procedures. $I_{p}$ and $I_{s}$ : dpm of ${ }^{3} \mathrm{H}$-labeled corticosteroid added to sample and standard sample.

\section{Fluorometric Determination of Cortisol and} Corticosterone in Plasma

The method of determination was reported in detail in previous paper (Kunugi et al., 1972). To $1 \mathrm{~m} l$ plasma, $1 \times 10^{5} \mathrm{dpm}$ each cortisol- ${ }^{3} \mathrm{H}$ and corticosterone- ${ }^{3} \mathrm{H}$ were added, then extracted with dichloromethane. The extract was submitted to repeated twice TLC with chloroform-ethanol $(9: 1)$ and benzene-acetone $(1: 1)$. The silica gel in the area of spots of cortisol (I) and corticosterone (II) were scraped off and eluted with dichloromethane-metha- 
nol (2: 1). The solvent was evaporated from the ninetenths of the eluted solution, $4 \mathrm{ml}$ of sulfuric acidethanol $(65: 35)$ reagent was added, after $20 \mathrm{~min}$ at $45^{\circ} \mathrm{C}$ for $\mathrm{I}$ and $10 \mathrm{~min}$ for II, fluorescence intensity of the solution was measured at $525 \mathrm{~nm}$, with an excitation wavelength of $470 \mathrm{~nm}$ (Peterson, 1957a). The amount of I and II were calculated from the calibration curves and corrected with the recovery rate obtained from the radioactivity of ${ }^{3} \mathrm{H}$ for remaining one-tenth fraction of the eluted solution.

3. Separation of Free and Protein-Bound Cortisol by' Gel Filtration

To $1 \mathrm{ml}$ of plasma, $1 \times 10^{5} \mathrm{dpm}$ of cortisol- ${ }^{3} \mathrm{H}$ was added, the mixture was incubated at $37^{\circ} \mathrm{C}$ for $2 \mathrm{hr}$, loaded on a column $(10 \times 300 \mathrm{~mm})$ of Sephadex G-25 (fine) swelled with Sörensen's phosphate buffer (pH 7.38), and the column was eluted with the same buffer. The effluent was separated into $2 \mathrm{ml}$ fractions and each fraction was measured for absorbance at $280 \mathrm{~nm}$, and $0.5 \mathrm{ml}$ of each fraction was collected in a counting vial, $10 \mathrm{~m} l$ of hydrophilic liquid scintillator was added and radioactivity of ${ }^{3} \mathrm{H}$ was measured in a liquid scintillation counter, and the elution curve was prepared.

4. Fractional Determination of Free and ProteinBound Cortisol and Corticosterone in Plasma

One milliliter of plasma was loaded on a column $(10 \times 300 \mathrm{~mm})$ of Sephadex G-25 (fine) swelled with Sörensen's phosphate buffer ( $\mathrm{pH}$ 7.38), and the column was eluted with the same buffer to separate into free and protein-bound fractions. To each of these fractions, $1 \times 10^{5} \mathrm{dpm}$ each of cortisol- ${ }^{3} \mathrm{H}$ and corticosterone- ${ }^{3} \mathrm{H}$ were added and each was extracted with three $5 \mathrm{ml}$ portions of dichloromethane. The extracts were processed as outlined in the part of isotope derivative method to obtain the amount of cortisol and corticosterone.

\section{Results}

\section{Condition for Mutual Separation of Corticosteroids}

To $1 \mathrm{ml}$ of plasma, $1 \times 10^{5} \mathrm{dpm}$ each of ${ }^{3} \mathrm{H}$-labeled corticosteroids were added, and the mixture was processed as outlined in the part of isotope derivative method to obtain corticosteroid thiosemicarbazones. These thiosemicarbazones were submitted to repeated TLC at $10^{\circ} \mathrm{C}$ with four kinds of solvent systems, and the radioactivities of ${ }^{3} \mathrm{H}$ and ${ }^{35} \mathrm{~S}$ of the spots of cortisol, corticosterone, aldosterone, deoxycorticosterone, and cortisone
Table 1. Isotope ratios in consecutive thin-layer chromatography of corticosteroid- ${ }^{3} \mathrm{H}$ thiosemicarbazones- ${ }^{35} \mathrm{~S}$

\begin{tabular}{lllll}
\hline \multirow{2}{*}{ Steroid } & \multicolumn{5}{c}{${ }^{3} \mathrm{H} /{ }^{35} \mathrm{~S}$ ratio } \\
\cline { 2 - 5 } & 1 st & 2nd & 3rd & 4th \\
\hline Cortisol & 10.21 & 11.35 & 11.48 & 11.47 \\
Corticosterone & 10.01 & 11.18 & 11.79 & 11.81 \\
Aldosterone & 12.10 & 12.78 & 12.91 & 12.90 \\
$\begin{array}{l}\text { Cortisone } \\
\begin{array}{l}\text { Deoxy- } \\
\text { corticosterone }\end{array}\end{array}$ & 11.92 & 12.78 & 13.05 & 13.06 \\
\hline
\end{tabular}

Solvent system: 1st, $\mathrm{CHCl}_{3}$-EtOH (9:1) 2nd, cyclohexane-isoPrOH $(7: 3)$ 3rd, benzene- $\mathrm{Me}_{2} \mathrm{CO}$ (1: 1) 4th, AcOEt.

thiosemicarbazones were measured for each extracts at development to obtain the ${ }^{3} \mathrm{H} /{ }^{35} \mathrm{~S}$ ratio, respectively. As shown in Table 1, the repeated TLC consecutively remove the contaminants and ${ }^{3} \mathrm{H} /{ }^{35} \mathrm{~S}$ ratio gradually increased. It was thereby found that this ratio became constant by four repeated TLC with the solvent systems of chloroform-ethanol $(9: 1)$, cyclohexane-isopropanol $(7: 3)$, benzene-acetone $(1: 1)$, and ethyl acetate, consecutively, and that these corticosteroid thiosemicarbazones were separated from the thiosemicarbazones of coexisting $\Delta^{4}-3$-ketosteroids and carbonyl compounds in radiochemically pure state.

\section{Comparison with Fluorometric Determi- nation}

Cortisol and corticosterone in human plasma were submitted to determined by double isotope derivative dilution method and conventional known fluorometric method, and the determined values obtained from these two methods were compared. As shown in Figure la, b, comparison of results obtained in the same plasma sample using double isotope derivative dilution method and fluorometric method showed a good correlation, correlation coefficients were 0.998 and 0.994 for cortisol and corticosterone, respectively. 


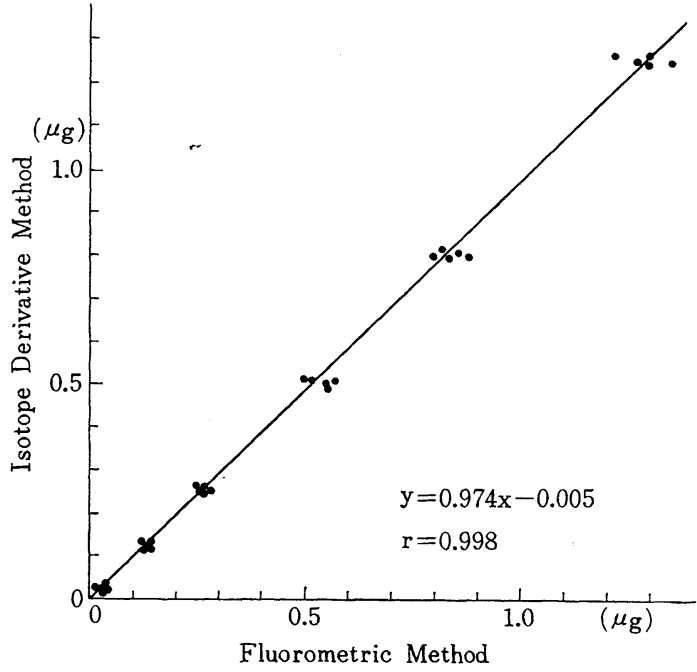

Fig. 1a. Comparison of determined values of cortisol in plasma by double isotope derivative dilution method and flurometric method.

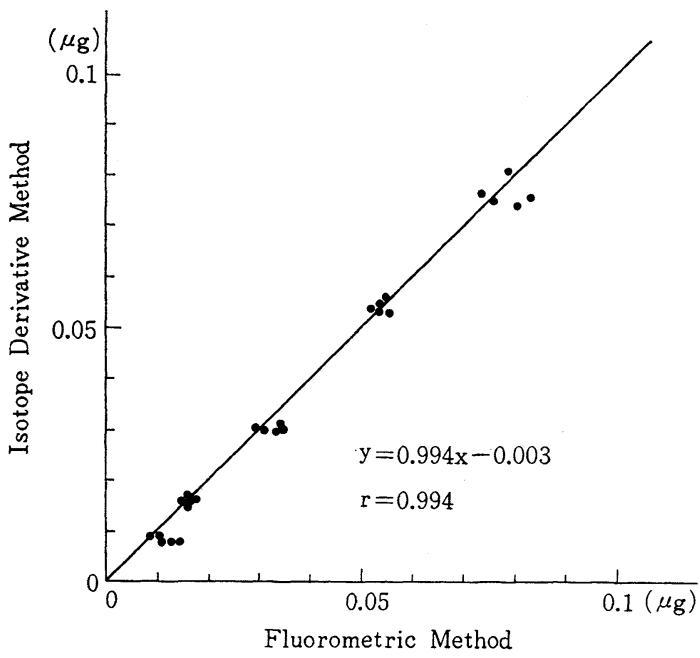

Fig. 1b. Comparison of determined values of corticosterone in plasma by double isotope derivative dilution method and fluorometric method.

\section{Effect of Coexisting Substances}

Prepared samples were obtained by the addition of cortisone $(0-10 \mu \mathrm{g})$ as coexisting substance to cortisol or corticosterone (0.001$10 \mu \mathrm{g})$. To each of these sample, $1 \times 10^{5} \mathrm{dpm}$ each of cortisol $-{ }^{3} \mathrm{H}$ or corticosterone $-{ }^{3} \mathrm{H}$ was added and the mixture was processed as outlined in the part of isotope derivative method to obtain the amount of cortisol or corticosterone. The result of determination of cortisol in these sample, which were added with cortisone as coexisting substance to cortisol, was shown in Table 2a. In the case of added cortisone (VI) as coexisting substance to corticosterone, the result of determination of corticosterone was shown in Table $2 b$. Therefore, it was found that this method of determination was not affected even if coexisting substance like cortisone was present in amount 1,000 times that of cortisol or corticosterone. Furthermore, it was found that this method of determination was also not affected even if coexisting substances like thiosemicarbazide${ }^{35} \mathrm{~S}$ reacting substances such as $11-$ deoxycortisol (VII), deoxycorticosterone (VIII), dexamethasone (IX), paramethasone (X), prednisolone (XI), progesterone (XII), testosterone (XIII), glucose and acetone were present in amount 1,000 times of cortisol or corticosterone.

The results of determination of cortisol and corticosterone in plasma samples, which were prepared by the addition of $10 \mu \mathrm{g}$ each of VIXIII, glucose, and acetone as coexisting substance to $1 \mathrm{~m} l$ each of plasma, were shown in Table 3. The determined values of cortisol in plasma was not affected even in the presence of about 40 times the amount of structually similar $\Delta^{4}-3$-ketosteroids, glucose, and acetone, the relative standard deviation being $1-2 \%$. The determination of corticosterone in plasma was also not affected even in the presence of about 700 times the amount of these coexisting substances.

\section{Effect of Binding of Cortisol and Corti- costerone with Plasma Protein on Solvent Extraction \\ Five milliliters each of the free and protein-} bound fractions obtained by gel filtration (Sephadex G-25) were extracted three times $5 \mathrm{ml}$ each of dichloromethane, dichloroethane, chloroform, and ethyl acetate, radioactivity 
Table 2a. Effect of coexisting substances on determination of cortisol

\begin{tabular}{|c|c|c|c|c|c|}
\hline \multirow[b]{2}{*}{$\begin{array}{l}\text { Sample } \\
\text { Taken }(\mu \mathrm{g})\end{array}$} & \multicolumn{2}{|c|}{ Coexisting substances* } & \multicolumn{3}{|c|}{ Cortisol } \\
\hline & Added $(\mu \mathrm{g})$ & Ratio** & Found $(\mu \mathrm{g})$ & Recovery $(\%)$ & $\begin{array}{l}\text { Relative } \\
\text { standard } \\
\text { deviation }(\%)\end{array}$ \\
\hline \multirow[t]{4}{*}{0.001} & 10.00 & 10,000 & 0.0011 & 114.3 & 8.28 \\
\hline & 5.00 & 5,000 & 0.0011 & 110.5 & 5.35 \\
\hline & 1.00 & 1,000 & 0.0011 & 107.2 & 3.43 \\
\hline & 0 & 0 & 0.0010 & 104.3 & 3.15 \\
\hline \multirow[t]{4}{*}{0.01} & 10.00 & 1,000 & 0.0105 & 105.5 & 1.88 \\
\hline & 5.00 & 500 & 0.0103 & 103.2 & 1.65 \\
\hline & 1.00 & 100 & 0.0102 & 102.1 & 1.47 \\
\hline & 0 & 0 & 0.0099 & 99.4 & 1.45 \\
\hline \multirow[t]{4}{*}{0.10} & 10.00 & 100 & 0.1048 & 104.8 & 1.77 \\
\hline & 5.00 & 50 & 0.1021 & 102.1 & 1.80 \\
\hline & 1.00 & 10 & 0.0998 & 99.8 & 1.54 \\
\hline & 0 & 0 & 0.1007 & 100.7 & 1.38 \\
\hline \multirow[t]{4}{*}{1.00} & 10.00 & 10 & 1.018 & 101.8 & 1.67 \\
\hline & 5.00 & 5 & 1.013 & 101.3 & 1.72 \\
\hline & 1.00 & 1 & 0.999 & 99.9 & 1.55 \\
\hline & 0 & 0 & 1.011 & 101.1 & 1.43 \\
\hline \multirow[t]{4}{*}{5.00} & 10.00 & 2 & 5.21 & 104.2 & 1.50 \\
\hline & 5.00 & 1 & 5.09 & 101.8 & 1.07 \\
\hline & 1.00 & 0.2 & 5.11 & 102.2 & 1.11 \\
\hline & 0 & 0 & 4.99 & 99.9 & 1.16 \\
\hline \multirow[t]{4}{*}{10.00} & 10.00 & 1 & 10.15 & 101.5 & 1.21 \\
\hline & 5.00 & 0.5 & 9.89 & 98.9 & 1.09 \\
\hline & 1.00 & 0.1 & 10.18 & 101.8 & 1.07 \\
\hline & 0 & 0 & 10.05 & 100.5 & 0.98 \\
\hline
\end{tabular}

* Cortisone.

** Weight ratio of coexisting substances to cortisol.

of ${ }^{3} \mathrm{H}$ was measured with each extract, and extraction rate of each solvent was calculated. As shown in Table 4, extraction with dichloromethane was found to extract more than $90 \%$ of both the free and protein-bound cortisol and corticosterone, indicating that the protein-bound form was dissociated during solvent extraction and all were extracted in the free form. It was found that, solvent extraction of corticosteroids from plasma were not affected the binding of corticosteroids with plasma protein (transcortin), and the total amount of corticosteroids were determined in free form. Therefore, dichloromethane was used as a most suitable solvent in the extraction of corticosteroids from plasma. According this method, the loss during the solvent extraction can be corrected because ${ }^{3} \mathrm{H}$-labeled cortisol and corticosterone are preliminarily added as an indicator for correction of the loss during the analytical procedure.

\section{Determination of Corticosteroids in Plasma}

On the basis of these results, it would become possible to carry out microdetermination of corticosteroids in plasma by the double isotope derivative dilution method. There is a diurnal variation in the blood level of corticosteroids, even under normal condition (Peterson and Wyngaarden, 1956). The determined values of five kinds of corticosteroids in plasma obtained from human male blood 
Table 2b. Effect of coexisting substances on determination of corticosterone

\begin{tabular}{|c|c|c|c|c|c|}
\hline \multirow[b]{2}{*}{$\begin{array}{l}\text { Sample } \\
\text { Taken }(\mu \mathrm{g})\end{array}$} & \multicolumn{2}{|c|}{ Coexisting substances* } & \multicolumn{3}{|c|}{ Corticosterone } \\
\hline & Added $(\mu \mathrm{g})$ & Ratio** & Found $(\mu \mathrm{g})$ & Recovery (\%) & $\begin{array}{l}\text { Relative } \\
\text { standard } \\
\text { deviation }(\%)\end{array}$ \\
\hline \multirow[t]{4}{*}{0.001} & 10.00 & 10,000 & 0.0011 & 113.8 & 9.07 \\
\hline & 5.00 & 5,000 & 0.0011 & 110.4 & 6.56 \\
\hline & 1.00 & 1,000 & 0.0011 & 107.1 & 4.35 \\
\hline & 0 & 0 & 0.0010 & 101.5 & 3.72 \\
\hline \multirow[t]{4}{*}{0.01} & 10.00 & 1,000 & 0.0104 & 104.2 & 2.05 \\
\hline & 5.00 & 500 & 0.0103 & 103.1 & 1.89 \\
\hline & 1.00 & 100 & 0.0102 & 102.5 & 1.67 \\
\hline & 0 & 0 & 0.0101 & 101.0 & 1.70 \\
\hline \multirow[t]{4}{*}{0.10} & 10.00 & 100 & 0.1021 & 102.1 & 1.54 \\
\hline & 5.00 & 50 & 0.1051 & 105.1 & 1.69 \\
\hline & 1.00 & 10 & 0.0993 & 99.3 & 1.37 \\
\hline & 0 & 0 & 0.1013 & 101.3 & 1.43 \\
\hline \multirow[t]{4}{*}{1.00} & 10.00 & 10 & 0.9831 & 98.3 & 1.73 \\
\hline & 5.00 & 5 & 0.9904 & 99.0 & 1.66 \\
\hline & 1.00 & 1 & 1.0125 & 101.3 & 1.52 \\
\hline & 0 & 0 & 1.0073 & 100.7 & 1.47 \\
\hline \multirow[t]{4}{*}{5.00} & 10.00 & 2 & 5.031 & 100.6 & 1.34 \\
\hline & 5.00 & 1 & 5.102 & 102.0 & 1.28 \\
\hline & 1.00 & 0.2 & 4.972 & 99.4 & 1.09 \\
\hline & 0 & 0 & 4.991 & 99.9 & 1.07 \\
\hline \multirow[t]{4}{*}{10.00} & 10.00 & 1 & 10.08 & 100.8 & 1.20 \\
\hline & 5.00 & 0.5 & 10.12 & 101.2 & 1.15 \\
\hline & 1.00 & 0.1 & 9.85 & 98.5 & 1.10 \\
\hline & 0 & 0 & 10.03 & 100.3 & 1.09 \\
\hline
\end{tabular}

* Cortisone

** Weight ratio of coexisting substances to corticosterone.

Table 3. Effect of other steroids and carbonyl compounds on determination of cortisol and corticosterone in plasma

\begin{tabular}{|c|c|c|c|c|c|}
\hline \multirow{3}{*}{ No. } & \multirow{3}{*}{ Compound* } & \multicolumn{4}{|c|}{ Determined values, $\mu \mathrm{g} / 100 \mathrm{~m} l$ plasma } \\
\hline & & \multicolumn{2}{|c|}{ Cortisol } & \multicolumn{2}{|c|}{ Corticosterone } \\
\hline & & Mean $(n=5)$ & $\begin{array}{l}\text { Relative standard } \\
\text { deviation }(\%)\end{array}$ & Mean $(n=5)$ & $\begin{array}{l}\text { Relative } \\
\text { standard } \\
\text { deviation }(\%)\end{array}$ \\
\hline 1 & Cortisone & 23.53 & 2.05 & 1.59 & 2.23 \\
\hline 2 & 11-Deoxycortisol & 22.41 & 1.53 & 1.52 & 1.98 \\
\hline 3 & Deoxycorticosterone & 22.38 & 1.24 & 1.47 & 1.29 \\
\hline 4 & Dexamethasone & 22.43 & 1.35 & 1.58 & 1.39 \\
\hline 5 & Paramethasone & 21.10 & 1.21 & 1.47 & 1.51 \\
\hline 6 & Prednisolone & 23.55 & 1.53 & 1.51 & 1.88 \\
\hline 7 & Progesterone & 22.10 & 0.98 & 1.43 & 1.35 \\
\hline 8 & Testosterone & 22.18 & 1.27 & 1.45 & 1.09 \\
\hline 9 & Glucose & 22.15 & 1.38 & 1.49 & 1.21 \\
\hline 10 & Acetone & 21.93 & 1.05 & 1.53 & 1.18 \\
\hline 11 & None & 22.80 & 1.03 & 1.49 & 1.09 \\
\hline
\end{tabular}

* Added $10 \mu \mathrm{g}$ each of compounds to $1 \mathrm{~m} l$ each of plasma. 
Table 4. Recovery of free and protein-bound cortisol and corticosterone by solvent extraction

\begin{tabular}{|c|c|c|c|c|}
\hline \multirow{3}{*}{ Solvent } & \multicolumn{4}{|c|}{ Recovery $(\%)$} \\
\hline & \multicolumn{2}{|c|}{ Cortisol } & \multicolumn{2}{|c|}{ Corticosterone } \\
\hline & Free & $\begin{array}{l}\text { Protein- } \\
\text { bound }\end{array}$ & Free & $\begin{array}{l}\text { Protein- } \\
\text { bound }\end{array}$ \\
\hline $\begin{array}{l}\text { Dichloro- } \\
\text { methane }\end{array}$ & 91.79 & 91.25 & 90.78 & 90.18 \\
\hline Ethyl acetate & 85.20 & 87.50 & 89.30 & 88.23 \\
\hline Chloroform & 82.80 & 87.95 & 88.10 & 87.13 \\
\hline 1,2- & $e^{78.50}$ & 72.33 & 72.27 & 76.26 \\
\hline
\end{tabular}

collected at 4 p.m., the time at which the blood level of corticosteroids is known to show a minimum level during the day, were presented in Table 5. Cortisol and corticosterone were determined with good precision, with relative standard deviation of about $1.3-1.5 \%$, when $1 \mathrm{~m} l$ of plasma was used. Aldosterone, deoxycorticosterone, and cortisone were also determined with good precision, with relative standard deviation of about $3-6 \%$, when $1 \mathrm{~m} l$ of plasma was used. Nevertheless, it was not possible to carry out determination of 11-dehydrocorticosterone in plasma by this isotope derivative method, when $1 \mathrm{ml}$ of plasma was used, because of its amount in plasma is trace.
Table 5. Determination of corticosteroids in human plasma*

\begin{tabular}{lcc}
\hline \hline \multirow{2}{*}{ Steroid } & \multicolumn{2}{c}{ Determined values } \\
\cline { 2 - 3 } & $\begin{array}{l}\text { Mean }(n=5) \\
(\mu \mathrm{g} / 100 \mathrm{~m} l)\end{array}$ & $\begin{array}{l}\text { Relative } \\
\text { standard } \\
\text { deviation }(\%)\end{array}$ \\
\hline Cortisol & 18.117 & 1.26 \\
Corticosterone & 1.552 & 1.49 \\
Aldosterone & 0.213 & 3.08 \\
Cortisone & 0.124 & 4.93 \\
Deoxycorticosterone & 0.033 & 6.08 \\
\hline
\end{tabular}

* Obtained from human blood collected at 4 p.m.

\section{Fractional Determination of Free and} Protein-Bound Cortisol and Corticosterone in Plasma

One milliliter of plasma was processed as outlined in the part of gel filtration method to obtain the free and protein-bound fraction. As shown in Figure 2, gel filtration through Sephadex G-25 dives free and protein-bound cortisol fractions separately. The same separation was made on corticosterone by incubating a mixture of plasma and corticosterone${ }^{3} \mathrm{H}$, and separating the two forms by gel filtration.

On the basis of the results, cortisol and corticosterone in free and protein-bound frac-

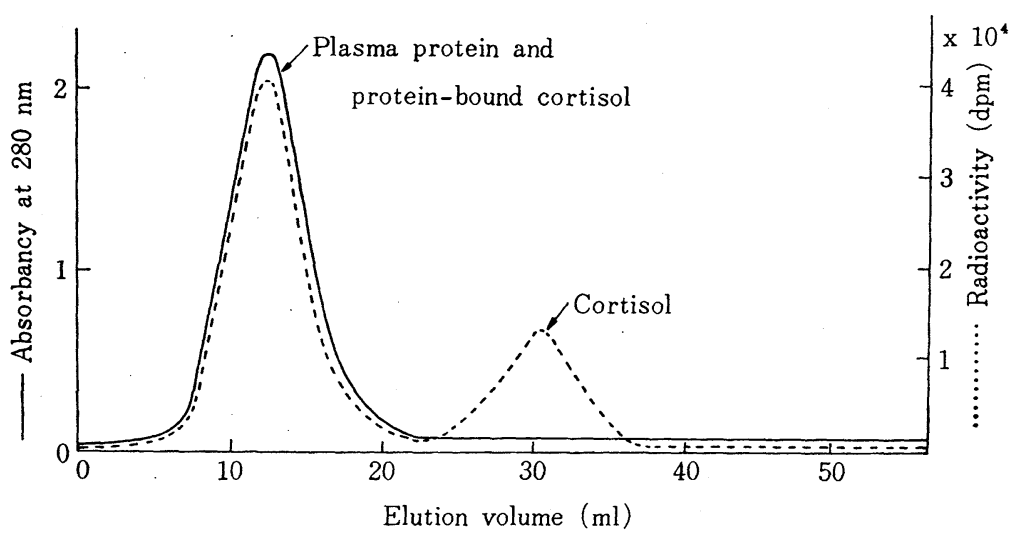

Fig. 2. Separation of free and protein-bound cortisol with Sephadex G-25 (fine).

Sample: $1 \mathrm{~m} l$ of plasma containing $1 \times 10^{5} \mathrm{dpm}$ of cortisol- ${ }^{3} \mathrm{H}$

Bed dimensions: $10 \times 300 \mathrm{~mm}$

Eluant: Sörensen's phosphate buffer ( $\mathrm{pH} 7.38)$.

Flow rate: $0.8 \mathrm{ml} / \mathrm{min}$. 
Table 6. Determination of free and protein-bound cortisol and corticosterone in plasma

\begin{tabular}{lcccc}
\hline & \multicolumn{2}{c}{ Cortisol* } & \multicolumn{2}{c}{ Corticosterone* } \\
\cline { 2 - 5 } No. & Free & $\begin{array}{l}\text { Protein- } \\
\text { bound }\end{array}$ & Free & $\begin{array}{l}\text { Protein- } \\
\text { bound }\end{array}$ \\
\hline 1 & 1.77 & 17.05 & 0.17 & 1.68 \\
2 & 1.81 & 18.15 & 0.19 & 1.72 \\
3 & 1.79 & 16.73 & 0.20 & 1.87 \\
4 & 1.85 & 17.31 & 0.17 & 1.69 \\
5 & 1.91 & 18.01 & 0.19 & 1.80 \\
Mean $(n=5)$ & 1.83 & 17.45 & 0.18 & 1.75 \\
$\begin{array}{c}\text { Standard } \\
\text { deviation }\end{array}$ & 0.116 & 1.064 & 0.014 & 0.081 \\
$\begin{array}{c}\text { Relative } \\
\text { standard (\%) } \\
\text { deviation }\end{array}$ & 4.20 & 4.15 & 7.83 & 4.64 \\
\hline
\end{tabular}

* $\mu \mathrm{g} / 100 \mathrm{ml}$ plasma.

tions were determined by the isotope derivative method after their gel filtration as a pretreatment.

The result of fractional determination of free and protein-bound cortisol and corticosterone in plasma was given in Table 6. It is found that the values of free cortisol and corticosterone were 1.83 and $0.18 \mu \mathrm{g} / 100 \mathrm{ml}$ plasma, and protein-bound cortisol and corticosterone were 17.45 and $1.75 \mu \mathrm{g} / 100 \mathrm{ml}$ plasma, respectively. These analytical results revealed that the free cortisol and corticosterone having physiological activity were present in about $10 \%$ of total cortisol and corticosterone in plasma.

\section{Discussion}

In the diagnosis of adrenocortical and pituitary functions, diagnosis and prognostic observations on secondary hypofunctions of adrenal cortex by the administration of synthetic adrenocortical steroids, and studies on the mechanism of adrenocortical stimulation by $\mathrm{ACTH}$, it is necessary to determine the blood level of cortisol, corticosterone, aldosterone, deoxycorticosterone, and cortisone at definite time intervals after administration of ACTH (Hoffmann, 1962),
SU-4885 (Metopirone) (Liddle et al., 1959), or dexamethasone (Liddle, 1960). For this reason, it is desirable to simultaneous determination of corticosteroids from the same sample. It was found that the above five kinds of corticosteroid in plasma were determined by this double isotope derivative dilution method, with good accuracy and precision, when $1 \mathrm{~m} l$ of plasma was used. In addition, this determination is not affected by the presence of more than 1,000-fold quantity of structurally similar $\Delta^{4}$-3-ketosteroids such as synthetic adrenocortical steroids, progesterone and testosterone, or carbonyl compounds such as glucose and acetone body if repeated thin-layer chromatography is carried out at $10^{\circ} \mathrm{C}$ (Kunugi et al., 1972), with four kinds of solvent systems for the development. Therefore, the combination of repeating thin-layer chromatography and the isotope derivative method of determination has made it possible to carry out simultaneous determination of various corticosteroids in plasma involving aldosterone from the same sample. Further, according to this method, the loss during extraction and separation steps can be corrected because ${ }^{3} \mathrm{H}$-labeled corticosteroids are preliminarily added as an indicator for correction of the loss during the analytical procedure.

The known normal values of corticosteroids in $100 \mathrm{ml}$ of plasma have been reported as follow: cortisol 10-20 $\mu \mathrm{g}$ (Sweat, 1955; Silber et al., 1958), corticosterone 1-4 $\mu \mathrm{g}$ (Peterson, 1957b), deoxycorticosterone 0.003$0.04 \mu \mathrm{g}$ (Nolten et al., 1968; Schambelan and Biglieri, 1970), aldosterone 0.003-0.15 $\mu \mathrm{g}$ (Peterson, 1964; Brodie et al., 1967), cortisone 1-5 $\mu \mathrm{g}$ (Magda, 1958; Murphy, 1967). The values of cortisol, corticosterone, and deoxycorticosterone in plasma determined by this isotope derivative method are in close agreement with values obtained by conventional methods. On the other hand, the determined value of aldosterone by this method was shown a slightly high value, and that of cortisone was shown a slightly low value. 
Furthermore, the corticosteroids are present in blood as a protein-bound form and in physiologically active free form. The blood level of cortisol and corticosterone is known to fluctuate markedly during stress, pregnancy, in Cushing's syndrome, Addison's disease, adrenogenital syndrome, hypofunction or hyperfunction of thyroid, kidney diseases, and liver dysfunction. For the elucidation of these mechanism, it becomes necessary to fractionally determine the free and proteinbound cortisol and corticosterone as the main two corticosteroids in plasma. This fractional determination has become possible by the isotope derivative method after separation of the free and protein-bound forms by gel filtration of plasma through Sephadex G-25.

\section{References}

Brodie, A., N. Shimizu, S. A. S. Tait and J. F. Tait (1967). J. Clin. Endocrinol. Metab. 27, 997.

Daughaday, W. H. (1958). J. Clin. Invest. 37, 511.

Hoffmann, K. (1962). Ann. Rev. Biochem. 31, 213.

Kunugi, A., U. Matsumoto, Y. Aizawa and Y. Nagase (1972). Chem. Pharm. Bull.
(Tokyo). "accepted"

Liddle, G. W., H. L. Estop, J. W. Kendall, W. C. Williams and A. W. Townes (1959). J. Clin. Endocrinol. 19, 875.

Liddle, G. W. (1960). Ibid. 20, 1539.

Magda, R. (1958). Australian J. Exptl. Biol. Med. Sci. 36, 555.

Murphy, B. E. P. (1967). J. Clin. Endocrinol. 27, 973.

Nolten, W., P. Vecsei, M. Kohler, I. Puriesz and H. P. Wolff. (1968). Verh. Deutsch. Ges. Inn. Med. 74, 1218.

Peterson, R. E. and J. B. Wyngaarden (1956). J. Clin. Invest. 35, 552.

Peterson, R. E. (1957a). J. Clin. Endocrinol. Metab. 17, 1150.

Peterson, R. E. (1957b). J. Biol. Chem. 225, 25. Peterson, R. E. Aldosterone (edited by E. E. Baulieu and P. Robel). Blackwell, Oxford, p. 145 (1964).

Schambelan, M. and E. G. Biglieri (1970). Clin. Res. 18, 125.

Seal, U. S. and R. P. Doe (1962). J. Biol. Chem. 237, 3136.

Silber, R. H., R. D. Busch and R. Oslapas (1958). Clin. Chem. 4, 278.

Slaunwhite, W. R. and A. A. Sandberg (1959). J. Clin. Invest. 38, 384.

Sweat, M. L. (1955). J. Clin. Endocrinol. Metab. 15, 1043. 